\title{
ANALISIS RISIKO USAHATANI TOMAT (Solanum lycopersicum) \\ VARIETAS PERMATA
}

(Suatu Kasus di Desa Cibeureum Kecamatan Sukamantri Kabupaten Ciamis)

Oleh:

Iqbal Apriadi $^{1}$, Yus Rusman ${ }^{2}$, Tito Hardiyanto ${ }^{3}$

1) Mahasiswa Fakultas Pertanian Universitas Galuh

2) Dosen Fakultas Pertanian Universitas Galuh

3) Dosen Fakultas Pertanian Universitas Galuh

\begin{abstract}
ABSTRAK
Penelitian ini dilaksanakan dengan tujuan untuk mengetahui : (1) Besarnya biaya dan pendapatan pada usahatani tomat per hektar per satu kali musim tanam. (2) Besarnya R/C pada usahatani tomat per hektar per satu kali musim tanam. (3) Besarnya koefisien variasipada usahatani tomat per hektar per satu kali musim tanam. Jenis penelitian yang digunakan adalah penelitian metode survey dengan mengambil kasus di Desa Cibeureum Kecamatan Sukamantri Kabupaten Ciamis. Responden yang dijadikan sebagai sampel dalam penelitian ini berjumlah 31 orang yang merupakan $30 \%$ dari populasi anggota yang berjumlah 105 orang dari petani tomat yang diambil secara acak sederhana (Simple Random Sampling). Hasil dari penelitian ini menunjukkan: Besarnya biaya yang dikeluarkan pada usahatani tomat di Desa Cubeureum Kecamatan Sukamantri sebesar Rp 26.735.765,penerimaan sebesar Rp 66.430.108,- sehingga pendapatanmya sebesar Rp 39.694.343,- per hektar per musim tanam. Besarnya R/C usahatani tomat di Desa Cibeureum Kecamatan Sukamantri sebesar 2,50 artinya setiap $R p$ 1,- biaya yang dikeluarkan pada usahatani tomat tersebut akan diperoleh penerimaan sebesar $R p$ 2,50,- sehingga pendapatan yang diperoleh sebesar $R p$ 1,50 hal ini menunjukkan bahwa usahatani tomat tersebut menguntungkan dan layak untuk diusahakan. Usahatani tomat di Desa Cibeureum Kecamatan Sukamantri mengandung risiko dengan nilai koefisien variasi sebesar 0,12 yang artinya setiap $R p$ 1,- dari keuntungan yang diperoleh petani, maka risiko atau kerugian yang dihadapi adalah sebesar 0,12 rupiah, dengan nilai batas bawah keuntungan sebesar Rp 30.079.307,- dimana angka tersebut menunjukkan jumlah kerugian yang mungkin ditanggung petani jika mengalami kerugian.
\end{abstract}

\section{Kata kunci : Tomat, Pendapatan, R/C, Risiko}

\section{PENDAHULUAN}

Pembangunan pertanian sangat berperan pentingdalam perekonomian nasional yaitu sebagaipembentukan kapital, penyediaan bahan pangan,bahan baku industri, pakan dan bioenergi,penyerap tenaga kerja, sumber devisa negara,sumber pendapatan serta pelestarian lingkunganmelalui praktek usahatani yang ramah lingkungan.Pembangunan pertanian bertujuan untukmeningkatkan pendapatan dan kesejahteraanpetani, mewujudkan swasembada panganberkelanjutan, dan meningkatkan penerimaandevisa (Departemen Pertanian, 2009).

Salah satu komoditas hortikultura adalah tanaman tomat, tanaman tomat termasuk tanaman semusim Ordo Solanales, family solanaceae, genus Lycopersicon, spesies Lycopersicon esculentum Mill. Tomat sangat bermanfaat bagi tubuh karena mengandung vitamin dan mineral yang diperlukan untuk pertumbuhan dan kesehatan. Buah tomat juga mengandung karbohidrat, protein, lemak dan kalori (Pudjiatmoko dan Atani, 2008).

Di Kabupaten Ciamis sendiri daerah potensial untuk penanaman dan pengembangan tomat terletak di Kecamatan Sukamantri tepatnya di Desa Cibeureumdengan luas panen 27 Hektar yang menghasilkan produksi tomat sebanyak 3.296,97 Kuintal dengan produktivitas sebanyak 122,11 Kuintal per Hektar (BP3K Kecamatan Sukamantri Kabupaten Ciamis 2014).

Perhitungan mengenai penerimaan yang diperoleh dari suatu usahatani yang dijalankan selalu dilakukan oleh para petani pada umumnya, hal ini sangat perlu dilakukan untuk mengatur seberapa besar keuntungan yang diperoleh dari suatu usahatani yang dijalankan, walaupun perhitungan tersebut tidak dilakukan secata terperinci dan tertulis. Menurut Suratiyah (2006), penerimaan adalah jumlah produksi dikalikan dengan harga jual satuan produksi. Dengan diketahuinya biaya dan penerimaan dari suatu 
usahatani maka pendapatan dari suatu usahatani dapat diketahui dengan menghitung selisih antara penerimaan dengan biaya produksi. Soekartawi (2006), menyatakan Pendapatan usahatani adalah selisih antara penerimaan dan semua biaya.

Akan tetapi sama seperti usaha lainnya dalam ushatanipun memiliki risiko, risiko usahatani terjadi selama proses produksi berlangsung dan risiko terhadap harga jual. Menurut petani terdapat beberapa faktor yang berkaitan dengan risiko, baik faktor eksternal maupun internal. Faktor ekternal ditunjukkan melalui perubahan iklim/cuaca, serangan OPT, harga sarana produksi, harga output, sedangkan faktor internal ditunjukkan melalui ketersediaan modal penguasaan lahan dan kemampuan manajerial (Saptana, Daryanto, dan Kuntjoro, 2009).

Berdasarkan uraian tersebut, maka penelitian ini dilaksanakan dengan tujuan untuk mengetahui: (1) Besarnya biaya, penerimaan dan pendapatan pada usahatani tomat per hektar per satu kali musim tanam. (2) Besarnya R/C pada usahatani tomat per hektar per satu kali musim tanam. (3) Besarnya koefisien variasipada usahatani tomat per hektar per satu kali musim tanam.

\section{METODE PENELITIAN \\ Jenis Penelitian}

Jenis penelitian yang digunakan adalah penelitian survey dengan mengambil kasus di Desa Cibeureum Kecamatan Sukamantri Kabupaten Ciamis. Metode survey merupakan suatu penelitian kuantitatif dengan menggunakan pertanyaan terstruktur, serta seluruh jawaban akan dicatat, diolah dan dianalisis (Prasetyo, dkk, 2008).Lokasi Penelitian ditentukan dengan sengaja (purposive), dengan pertimbangan Desa Cibeureum merupakan sentra produksi tomat di Kecamatan Sukamantri Kabupaten Ciamis.

\section{Oprasionalisasi Variabel}

Variabel yang akan diamati dalam penelitian ini meliputi :

1. Satu kali musim tanam dimulai dari pengolahan tanah sampai dengan panen berlangsung selama 3 bulan dengan varietas permata.

2. Usahatani tomat adalah suatu usaha mengolah sebidang tanah untuk ditanami tomat kemudian hasilnya dijual atau dikonsumsi.
3. Petani tomat adalah pelaku dalam kegiatan usahatani tomat.

4. Biaya adalah korbanan yang dikeluarkan untuk menghasilkan suatu produksi dan dinilai dalam satuan rupiah. Biaya dibagi menjadi dua, yaitu :

1) Biaya Tetap (Fixed cost) adalah biaya yang besar kecilnya tidak dipengaruhi oleh besar kecilnya produksi.

2) Biaya Variabel (Variable Cost) adalah biaya yang besar kecilnya dipengaruhi oleh besar kecilnya produksi dan habis dalam satu kali proses produksi.

5. Jumlah produksi adalah banyaknya tomat yang dihasilkan per hektar per satu kali musim tanam, dan dinyatakan dalam satuan kilogram $(\mathrm{Kg})$.

6. Harga jual produk adalah, harga penjualan tomat yang diterima oleh petani yang dinyatakan dalam satuan rupiah per kilogram $(\mathrm{Rp} / \mathrm{Kg})$.

7. Penerimaan yaitu jumlah hasil produksi dikalikan dengan harga satuan produksi total yang dinilai dalam satuan rupiah, dan dinyatakan dalam satuan rupiah per satu kali proses produksi (Rp/satu kali musim tanam).

8. Pendapatan yaitu selisih antara penerimaan dengan biaya produksi dan dinyatakan dalam satuan rupiah per satu kali proses produksi ( $\mathrm{Rp} / \mathrm{satu}$ kali musim tanam).

9. $\mathrm{R} / \mathrm{C}$ adalah perbandingan antara penerimaan dengan biaya produksi.

10. Risiko adalah suatu kondisi tidak pasti dengan peluang kejadian tertentu yang menimbulkan konsekuensi yang tidak menguntungkan.

11. Koefisien Variasi adalah perbandingan antara simpangan standar dengan nilai ratarata yang sering dinyatakan dengan persentase yang berguna untuk melihat sebaran data dari rata-rata hitungnya.

12. Simpangan baku adalah adalah ukuran sebaran statistik yang paling lazim yang mengukur bagai mana data tersebar.

\section{Teknik Pengumpulan Data}

Teknik pengumpulan data yang dikumpulkan berupa data primer dan data sekunder. Data primer diperoleh dengan melakukan wawancara langsung kepada responden dengan menggunakan daftar pertanyaan atau kuesioner yang telah dipersiapkan sebelumnya. 
Pengumpulan data sekunder dilakukan melalui studi pustaka dan kunjungan ke dinas dan instansi terkait, yang ada hubungannya dengan penelitian ini.

\section{Teknik Penarikan Sampel}

Untuk menentukan responden yang dijadikan sebagai sampel dalam penelitian ini dilakukan secara purposive yang menurut Sugiyono (2010), "sampling purposive adalah teknik penentuan sampel dengan pertimbangan tertentu".

Responden dalam penelitian ini adalah petani yang berada di Desa Cibeureum yang melakukan usahatani tomat. Respondenpada penelitian ini berjumlah 31 orang yang merupakan $30 \%$ dari populasi yang berjumlah 105 orang dari petani tomat yang diambil secara acak sederhana (Simple Random Sampling). Menurut Arikunto (2008), Apabila responden kurang dari 100 lebih baik diambil semua hingga penelitiannya merupakan penelitian populasi sedangkan jika jumlah responden besar dapat diambil antara $10-15 \%$ atau $20-55 \%$ atau lebih.

\section{Rancangan Analisis Data}

\section{Analisis Biaya}

$\mathrm{TC}=\mathrm{TFC}+\mathrm{TVC}$

Keterangan :

TC : Total Cost (biaya total)

TFC : Total Fixed Cost (biaya tetap total)

TVC : Total Variable Cost (biaya variabel total)

(Soekartawi, 2006)

\section{Analisis Pendapatan dan Pemerimaan}

$$
\begin{array}{ll}
\pi & =\mathrm{TR}-\mathrm{TC} \\
\mathrm{TR} & =\mathrm{Hy} \cdot \mathrm{Y}
\end{array}
$$

Keterangan :

$\pi$ : Pendapatan (keuntungan)

TR : Total Revenue (penerimaan total)

TC : Total Cost (biaya total)

Hy : Harga jual produk

Y : Jumlah produk yang dihasilkan

\section{Analisis Imbangan antara Penerimaan} dengan Biaya atau $\mathrm{R} / \mathrm{C}$

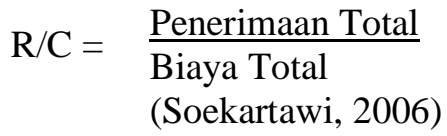

Dengan ketentuan sebagai berikut :
1) $\mathrm{R} / \mathrm{C}>1$, maka usaha tersebut menguntungkan sehingga layak untuk diusahakan.

2) $\mathrm{R} / \mathrm{C}=1$, maka usaha tersebut tidak untung dan tidak rugi (impas) sehingga tidak layak untuk diusahakan.

3) $\mathrm{R} / \mathrm{C}<1$, maka usaha tersebut rugi sehingga tidak layak untuk diusahakan.

\section{Analisis Risiko}

$$
\begin{aligned}
\mathrm{KV}= & \frac{S}{\mathrm{E}} \\
& \text { (Pappas dan Hirschey, } 1995 \text { dalam } \\
& \text { Heriani, dkk, 2013) }
\end{aligned}
$$

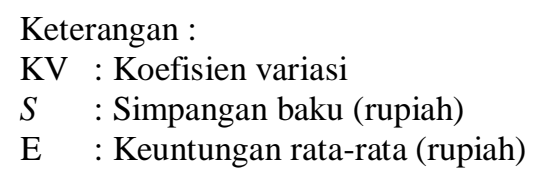

Untuk mengetahui simpangan baku dapat menggunakan rumus sebagai berikut (Sudjana, 2005) :

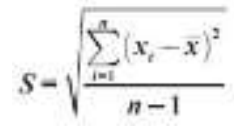

Semakin besar nilai koefisien variasi $(\mathrm{KV})$,semakin besar risiko yang harus ditanggung petanitomat. Batas bawah keuntungan (L) menunjukkan nilai nominal keuntungan terendah yang mungkin diterima oleh petani. Apabila nilainya kurang darinol, maka kemungkinan besar akan mengalami kerugian. Rumus batas bawah keuntungan (Kadarsan, 1995dalam Heriani, dkk, 2013):

$$
\begin{aligned}
& \mathrm{L}=\mathrm{E}-2 . S \\
& \text { Keterangan } \\
& \mathrm{L} \quad: \text { Batas bawah } \\
& \mathrm{E} \quad \text { : Rata-rata keuntungan yang diperoleh } \\
& S \quad: \text { Simpangan baku }
\end{aligned}
$$

\section{HASIL DAN PEMBAHASAN Identitas Responden}

Jumlah responden dalam penelitian ini berjumlah 31 orang. Umur responden yaitu berkisar antara 38-68 tahun, dimana sebanyak 3 orang $(10,00 \%)$ responden memiliki umur diatas 64 tahun sedangkan sisanya memiliki umur dibawah 64 tahun.

Pendidikan formal yang dicapai responden bervariatif yaitu berpendidikan SD sampai SMA, dengan rincian SD yaitu 21 orang $(68,00 \%)$ SMP yaitu $6(19,00 \%)$ SMA yaitu $4(13,00 \%)$. 
Berdasarkan hasil penelitian, pengalaman usahatani responden berkisar antara 5-20 tahun, sebanyak 24 orang $(77,00 \%)$ memiliki pengalaman antara 11-20 tahun, 7 responden (23,00\%)memiliki pengalaman 5-10 tahun.

Berdasarkan hasil penelitian sebagian besar responden memiliki tanggungan keluarga 4-6 orang, yaitu sebanyak 16 orang $(52,00 \%)$ sisanya sebanyak 15 orang $(48,00 \%)$ persen memiliki tanggungan keluarga antara 1-3 orang.

Hasil penelitian menunjukkan bahwa sebagian besar responden memiliki lahan dengan luas lahan garapan $>0,50$ hektar yaitu 23 orang $(74,19 \%)$ sedangkan sisanya 8 orang memiliki luas lahan garapan antara 0,25-0,50 hektar $(25,81 \%)$.

\section{Biaya dan Pendapatan Usahatani Tomat}

1) Biaya

Biaya yang dikeluarkan pada usahatani tomat ini meliputi biaya tetap dan biaya variabel. Biaya tetap meliputi biaya untuk pajak bumi dan bangunan, biaya penyusutan alat dan bunga modal tetap. Sedangkan biaya variabel meliputi biaya untuk pembelian sara produksi antara lain pembelian benih, pupuk, obat-obatan, penggunaan tenaga kerja, dan bunga modal variabel. Selengkapnya mengenai biaya pada usahatani tomat per hektar per satu kali musim tanam. Dapat dilihat pada Tabel 1.

Tabel 1. Biaya Usahatani Tomat per Hektar per Musim Tanam

\begin{tabular}{|c|l|r|r|}
\hline No & \multicolumn{1}{|c|}{ Jenis Biaya } & Jumlah (Rp) & Persentase (\%) \\
\hline 1 & Biaya Tetap & & \\
& • Pajak Bumi dan bangunan (PBB) & 50.000 & 0,19 \\
& • Penyusutan Alat & 5.001 .004 & 18,71 \\
& • Bunga Modal Tetap & 606.120 & 2,27 \\
& Biaya Tetap Total & 5.657 .124 & 21,16 \\
\hline 2 & Biaya Variabel & & \\
& • Benih & 936.559 & 3,50 \\
& - Pupuk Organik & 4.510 .753 & 16,87 \\
& - NPK Ponska & 2.863 .656 & 10,71 \\
& - Insektisida & 1.959 .140 & 7,33 \\
& - Fungisida & 1.327 .957 & 4,97 \\
& • Perangsang Buah & 483.871 & 1,81 \\
& • Tenaga Kerja & 6.738 .280 & 25,20 \\
& • Bunga Modal Variabel & 2.258 .426 & 8,45 \\
& Biaya Variabel Total & 21.078 .641 & 78,84 \\
\hline $\mathbf{3}$ & Biaya Total & $\mathbf{2 6 . 7 3 5 . 7 6 5}$ & $\mathbf{1 0 0 , 0 0}$ \\
\hline
\end{tabular}

Tabel 1. menunjukkan bahwa biaya tetap total yang dikeluarkan dalam melaksanakan usahatani tomat sebanyak Rp5.657.124,- yang terdiri dari pembayaran PBB sebesar Rp 50.000,- penyusutan alat sebesar Rp 5.001.004,- dan bunga modal tetap sebesar Rp 606.120,-

Biaya variabel total pada usahatani tomat sebesar Rp 21.078.641,- yang terdiri dari biaya pembelian benih sebesar Rp 936.559,- pupuk organik sebesar Rp 4.510.753,- NPK ponska sebesar Rp 2.863.656,- insektisida sebesar Rp 1.959.140,- fungisida sebesar Rp 1.327.957,- perangsang buah sebesar Rp 483.871,- tenaga kerja sebesar Rp 6.738.280,- dan bunga modal variabel sebesar Rp 2.258.426,-

Biaya total dalam usahatani tomat merupakan penjumblahan antara biaya tetap total dengan biaya variabel total. Biaya total pada usahatani tomat di Desa Cibeureum Kecamatan Sukamantri adalah sebesar Rp 26.735.765,-

2) Pendapatan

Penerimaan merupakan hasil perkalian antar jumlah produksi yang dihasilkan dengan harga jual produk, sedangkan pendapatan merupakan selisih antara penerimaan dengan biaya yang dikeluarkan dalam melaksanakan usahatani tomat. selengkapnya mengenai penerimaan dan pendapatan usahatani tomat di Desa Cibeureum Kecamatan Sukamantri dapat dilihat pada Tabel. 2 
Tabel 2. Biaya, Penerimaan dan Pendapatan Usahatani Tomat per Hektar per Musim Tanam

\begin{tabular}{|c|l|c|r|}
\hline No & \multicolumn{1}{|c|}{ Uraian } & Satuan & \multicolumn{1}{c|}{ Nilai } \\
\hline 1 & $\begin{array}{l}\text { Biaya Tetap } \\
\text { Total }\end{array}$ & $\mathrm{Rp}$ & 5.657 .124 \\
\hline 2 & $\begin{array}{l}\text { Biaya } \\
\text { Variabel Total }\end{array}$ & $\mathrm{Rp}$ & 21.078 .641 \\
\hline 3 & Biaya Total & $\mathrm{Rp}$ & 26.735 .765 \\
\hline 4 & Produksi & $\mathrm{Kg}$ & 33.215 \\
\hline 5 & Harga Jual & $\mathrm{Rp} / \mathrm{Kg}$ & 2.000 \\
\hline 6 & $\begin{array}{l}\text { Penerimaan } \\
\text { Total }\end{array}$ & $\mathrm{Rp}$ & 66.430 .108 \\
\hline 7 & Pendapatan & $\mathrm{Rp}$ & 39.694 .343 \\
\hline
\end{tabular}

Tabel 2. menunjukkan bahwa biaya total yang dikeluarkan petani dalam melaksanakan usahatani tomat sebesar Rp 26.735.765,- per hektar per musim taman, dengan demikian pendapatan petani sebesar Rp 39.694.343,- per hektar per musim tanam.

\section{R/C Usahatani Tomat}

$\mathrm{R} / \mathrm{C}$ merupakan perbandingan antara penerimaan dengan biaya, dan digunakan untuk melihat kelayakan dari suatu usaha. R/C pada usahatani tomat di Desa Cibeureum adalah sebagai berikut:

$$
\begin{aligned}
\mathrm{R} / \mathrm{C} & =\frac{\text { Penerimaan }}{\text { Biaya }} \\
& =\frac{66.430 .108}{26.735 .765} \\
& =2,50
\end{aligned}
$$

$\mathrm{R} / \mathrm{C}$ pada usahatani tomat di Desa Cibeureum sebesar 2,50 menunjukkan bahawa usahatani tomat tersebut menguntungkan dan layak untuk diusahakan sebab terbukti memberikan keuntungan kepada petani. R/C pada usahatani tomat sebesar 2,50 menunjukkan bahwa setiap Rp 1,- biaya yang dikeluarkan pada usahatani tomat tersebut akan diperoleh penerimaan sebesar $\mathrm{Rp} 2,50,-$ sehingga pendapatan yang diperoleh sebesar Rp 1,50,-

\section{Koefisien Variasi Usahatani Tomat}

Pada usahatani risiko atau kerugian adalah hal yang tidak dapat dihindarkan karena semua bentuk usaha pasti terdapat risiko didalamnya. Pada usahatani sendiri ada banyak faktor yang dapat mengakibatkan risiko atau kerugian diantaranya seperti serangan organisme pengganggu tanaman, perubahan iklim dan cuaca, modal, pengalaman berusahatani, kemampuan menejerial, keterbatasan informasi, biaya produksi, dan juga harga sarana produksi dan produk.

Adapun cara untuk memperkecil tinggat risiko diantaranya petani perlu mengetahui dengan tepat kapan waktunya musim tanam dimulai, keterlambatan penanaman dapat berakibat rendahnya produktivitas atau bahkan kegagalan panen. Selanjutnya dengan menciptakan benih atau bibit unggul yang relatif tahan terhadap perubahan lingkungan dan sarana produksi seperti pupuk dan obat-obatan. Namun untuk tahap sekarang risiko dapat diperkecil dengan membeli benih, pupuk dan obat-obatan yang memang memiliki kualitas yang baik dan bersertifikat.

Selanjutnya untuk mengetahui tingkat risiko dari suatu usahatani dapat menggunakan perhitungan koefisien variasi dengan rumus sebagai berikut :

$$
\begin{aligned}
& \mathrm{KV}=\frac{S}{\mathrm{E}} \\
& S=\sqrt{\frac{\sum_{i=1}^{n}\left(x_{i}-\bar{x}\right)^{2}}{n-1}} \\
& S=\sqrt{\frac{693.366 .823 .646 .340}{30}} \\
& =\quad \sqrt{23.112 .227 .454 .877} \\
& =4.807 .518 \\
& \mathrm{KV}=\frac{S}{\mathrm{E}} \\
& =\frac{4.807 .518}{39.694 .343} \\
& =\quad 0,1211134257 \approx 0,12
\end{aligned}
$$

Koefisien variasi usahatani tomat di Desa Cibeureum sebesar 0,12 menunjukkan bahwa setiap satu rupiah dari keuntungan yang diperoleh petani, maka risiko atau kerugian yang dihadapi adalah sebesar 0,12 rupiah.

Batas bawah keuntungan (L) adalah perhitungan yang dapat melihat berapakah nilai kerugian yang mungkin ditanggung pada petani apabila mengalami kerugian pada usahataninya.

$$
\begin{aligned}
\mathrm{L} & =\mathrm{E}-2 \mathrm{~S} \\
& =39.694 .343-(2.4 .807 .518) \\
& =30.079 .307
\end{aligned}
$$

Batas bawah pendapatan yang dihasilkan pada usahatani tomat di Desa Cibeureum sebesar 
Rp 30.079.307,- angka tersebut menunjukkan jumlah kerugian yang mungkin ditanggung petani jika terdapat kerugian atau risiko, oleh karena itu untuk dapat menekan risiko dan kerugian petani harus meningkatkan perawatan secara intensif dan mencermati perkembangan harga tomat yang ada di pasaran.

\section{KESIMPULAN DAN SARAN \\ Kesimpulan}

Berdaasarkan hasil dan pembahasan, maka dapat ditarik kesimpulan sebagai berikut :

1. Biaya yang dikeluarkan pada usahatani tomat di Desa Cubeureum Kecamatan Sukamantri sebesar Rp 26.735.765,- penerimaan sebesar Rp 66.430.108,- sehingga pendapatanya sebesar Rp 39.694.343,- per hektar per musim tanam.

2. R/C usahatani tomat di Desa Cibeureum Kecamatan Sukamantri sebesar 2,50 yang artinya setiap $\mathrm{Rp} 1$,- biaya yang dikeluarkan pada usahatani tomat tersebut akan diperoleh penerimaan sebesar $\mathrm{Rp}$ 2,50,- sehingga pendapatan yang diperoleh sebesar Rp 1,50 hal ini menunjukkan bahwa usahatani tomat tersebut menguntungkan dan layak untuk diusahakan.

3. Usahatani tomat di Desa Cibeureum Kecamatan Sukamantri mengandung risiko dengan nilai koefisien variasi sebesar 0,12 yang artinya setiap $\mathrm{Rp} 1$,- dari keuntungan yang diperoleh petani, maka risiko atau kerugian yang dihadapi adalah sebesar 0,12 rupiah, dengan nilai batas bawah keuntungan sebesar Rp 30.079.307,- dimana angka tersebut menunjukkan jumlah kerugian yang mungkin ditanggung petani juga mengalami kerugian.

\section{Saran}

Berdasarkan kesimpulan, maka dapat diajukan beberapa saran sebagai berikut:

1. Petani diharapkan dapat mempertahankan usahatani tomat mengingat secara ekonomi usahatani ini menguntungkan walaupun mengandung risiko. Selain itu, petani juga diharapkan dapat memperhatikan harga jual dan memberikan perawatan secara intensif sehingga pendapatan bisa lebih ditingkatkan dan dapat mengurangi risiko usahatani tomat.

2. Pemerintah melalui dinas terkait diharapkan dapat mengadakan atau meningkatkan kegiatan sekolah lapangan bagi petani agar petani dapat mengingkatkan produktivitas usahatani khususnya tomat sehingga dapat meningkatkan taraf hidup petani.

\section{DAFTAR PUSTAKA}

Arikunto, S. 2008. Prosedur Penelitian Suatu Pendekatan Praktik. Rineka Karya: Jakarta

Badan Penyuluhan Pertanian, Perikanan dan Kehutanan Kecamatan Sukamantri. 2014. Data Usahatani Tanaman Holtikultura BP3K Kecamatan Sukamantri Tahun 2013. Ciamis

Departemen Pertanian. 2009. Rancangan Rencana Strategis Departemen Pertanian Tahun 2009-2014. Kementrian Pertanian. Indonesia.www.deptan.go.id. Rancangan Renstra Deptan2010-2014 Lengkap. Diakses tanggal 27September 2014.

Heriani, N., Zakaria, W.A., dan Soelaeman A. 2013. "Analisis Keuntungan Dan Risiko Usahatani Tomat Di Kecamatan Sumberejo Kabupaten Tanggamus".Jurnal JIIA, Volume 1 No.2. Program Studi Agribisnis. Fakultas Pertanian. Universitas Lampung. Bandar Lampung

Kadarsan HW. 1995. Keuangan Pertanian dan Pembiayaan Perusahaan Agribisnis. PT.Gramedia Pustaka Utama: Jakarta.

Pappas JM. Hierschey, M. 1995. Ekonomi Managerial Edisi Keenam Jilid II. BinarupaAksara: Jakarta.

Prasetyo, Bambang dan Lina Miftahul Jannah. 2008. Metode Penelitian Kuantitatif. Rajawali Pres: Jakarta.

Pudjiatmoko dan Atani.T, 2008. Budidaya Tomat. BBPP Lembang. Lembang.(http://kamaja.bbpp lembang.inf o/ diakses 15 April 2015).

Saptana Arief D Heny KD. Kuntjoro. 2009. "Analisis Perilaku dan Strategi Pengelolaan Risiko Petani Cabai Merah pada Lahan Kering Dataran Tinggi di Jawa Tengah". Jurnal SosioEkonomika 15(2):92-105. Jurusan Sosial Ekonomi Pertanian, Fakultas Pertanian, Universitas Lampung. Bandar Lampung.

Soekartawi. 2006. Analisis Usaha Tani. UI Press: Jakarta.

Sudjana. 2005. Metoda Statistika. Tarsito: Bandung.

Sugiyono. 2010. Metode Penelitian Kuantitatif Kualitatif \& RND. Alfabeta: Bandung

Suratiyah, K. 2006. Ilmu Usahatani. Penebar Swadaya: Jakarta. 